\title{
Cultivating Composting Culture Activities among Citizens and Its Beneficial to Prolong the Landfill Lifespan
}

\author{
Irnis Azura Zakarya ${ }^{1,2 *}$, Khairul Azri Jamial ${ }^{1,2}$, and Norazlinda Mat Tanda ${ }^{1,2}$ \\ ${ }^{1}$ Centre of Excellence for Biomass Utilization, Universiti Malaysia Perlis \\ ${ }^{1}$ School of Environmental Engineering, Kompleks Pengajian Jejawi 3, Universiti Malaysia Perlis, \\ 02600, Arau, Perlis, Malaysia.
}

\begin{abstract}
Currently, the Ministry of Housing and Local Government manage solid waste in Malaysia, with the participation of the private sector. Food waste represents almost $60 \%$ of the total municipal solid waste disposed in the landfill. Material valorisation of food waste usually conducted by biological processes such as composting. Compost, an organic amendment, is the final product of the composting process. These processes are efficient, low cost and environmentally friendly alternative for managing food waste and are used extensively worldwide. Therefore, organic solid waste management practices program for the communities in Perlis was conducted. The main objective of this program was to instilling environment awareness especially among Perlis citizens. This study was investigated the impact of food waste or kitchen waste composting to the citizens in Perlis State and the beneficial of compost fertilizer to our environment especially in plant growth. Composting method was taught to the food premises owner, individuals, teachers, and students and their responses to the composting practices were then summarized. In future, we can prolong our landfill lifespan by practicing organic waste composting and can preserving our environment.
\end{abstract}

\section{Introduction}

Our country is struggling to reduce amount of municipal waste from dump onto landfill and food waste is one of main types of the municipal solid waste [1]. There were 30,000 kilogram of waste collected and dump onto the landfill daily recorded. More than $51 \%$ of wastes were dumped organic waste such as kitchen waste, food waste, garden waste and so on. On the other hand, inorganic wastes such as recyclable waste like plastics, papers, metals, electronic waste or e-waste and much more. This result brought us on shortens life span of landfill at every state in Malaysia. More than 100 landfills situated all over Malaysia and this is not included open dumping site. From 100 landfills, not all were sanitary landfill, which provided more technology and more efficient waste treatment or by-product treatment such as leachate.

\footnotetext{
*Corresponding author: irnis@unimap.edu.my
} 
There are three landfills site in Perlis, two were closed and one currently active landfill. The active landfill located at Padang Besar District. There are various methods in managing solid waste such as incinerator, Material Recovery Facility (MRF), landfill and also composting. Composting also known as an organic fertilizer producer through biological decomposition of organic waste that happened for centuries [2]. Composting is an environmentally friendly technology and can be an effectively waste management strategy especially for food waste [3]. Studied claimed that composting is a biological process which organic matter can be utilized by aerobic thermophilic and mesophilic microorganisms as substrate and mainly converted into mineralized products $\left(\mathrm{CO}_{2}, \mathrm{H}^{2} \mathrm{O}\right.$, $\mathrm{NH}^{+4}$ ) or stabilized organic matter (mostly as humic substances) [4] and also can adds nutrients to the soil surrounding [5].

\section{Materials and Methods}

Several stages were introduced during the program. Fig. 1 show preparation for food waste composting process process in this program.

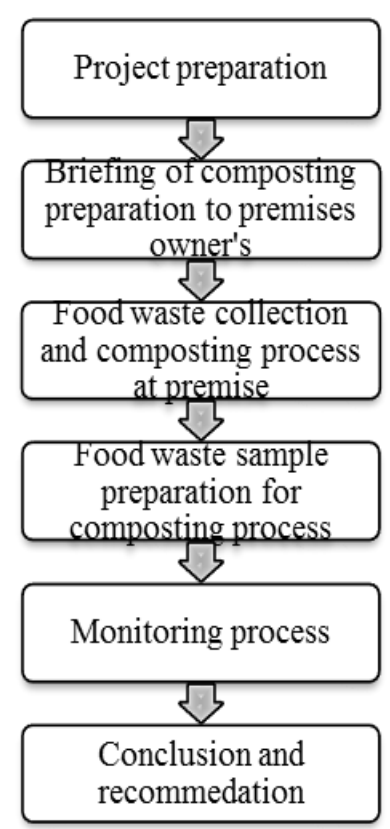

Fig. 1. Preparation for food waste composting at the premises.

\subsection{Compost material}

Fermented solution was prepared before it's given to the premises. Materials that needed for compost preparation are 'tempe', brown sugar, rice husk and black soil. All the material were given to the premises and showed to the owner of premises. 


\subsection{Composting process (Takakura method)}

Takakura Method was used in this program since it is easier and takes less space to do. It took three stages on making the Best regards,. For the first stage, fermentation solution (Effective Microorganisms (EM)) was made to culture bacteria. This fungal and bacteria cultures were added to accelerate the degradation process in the compost [2]. Two kilograms of brown sugar were mixed with 20 litres of water. Then four pieces of fermented soybean were put into the brown sugar water and the container was closed for a week for fermentation process to be done.

For the Stage 2, bucket with soil and rice husk were prepared as compost medium. Rice husk was used as bulking agent to adjust the moisture content and Carbon Nitrogen ratio [3]. Rice husk also act as oxygen access agent for bacteria to breath from the compacted soil. The soil and rice husk were mixed with the prepared EM and then leaved it for a week until white mold appeared. When the white mold has appeared, food waste can now be put inside the compost for the bacteria to degrad into smaller size.

Temperature is the most important parameter for affecting the compost process. To avoid pathogens and weeds, the temperature should be remain in thermophilic condition which is range $50-60^{\circ} \mathrm{C}$ [6] the compost must experience the temperature exceeding $55^{\circ} \mathrm{C}$ for at least three (3) days so that pathogens and weeds can be eliminated [7].

During composting, microorganism needs moisture to transporting the dissolved nutrients required for physiological and metabolic activities [8]. Compost was monitored to make sure not exceeding $60 \%$ of moisture content. If there is too much water droplet, the compost might be too wet since food waste consumed almost $65-80 \%$ of moisture $[9,10]$.

\subsection{Food premises and program organized}

From January 2016 until July 2017, there were 25 food premises and schools get involved in this program. All participants were given all the compost materials and tools provided by the PPKAS and SWCorp for the first time basis. They were taught on how to prepare compost from food waste and will be monitored every week to overcome incoming problems or any advice that needed.

On 18 April 2017, School of Environmental Engineering has organised a program to educate citizens regarding food waste composting. There were almost 50 participants joining this one-day program that happened at Multipurpose Room, School of Environmental Engineering.

\subsection{Parameter analysis}

Compost samples from selected premises in this study were tested for physical and chemical parameters. Every samples were tested by three (3) times and average value were recorded. In physical parameter, the $\mathrm{pH}$ value and temperature was measured. The $\mathrm{pH}$ values of the compost were determined by mixing the compost into distilled water. 10 gram of waste was weighed and $25 \mathrm{~mL}$ distilled water was measured and mixed in a beaker. The samples were stirred for 10 minutes. After that, when the sample have settled after 3 minutes, the sample were tested with $\mathrm{pH}$ meter to get the reading. The temperature was taken for 7 days continuously to record the changes in temperature during composting process. Three times of reading were taken to have the average value of compost. The chemical parameters were carried out according to APHA (2005) standard method. The chemical parameter including Nitrogen $(\mathrm{N})$, Phosphorus (P), and Potassium (K) were conducted in this study. 


\section{Results and discussion}

\subsection{Food premises and other related program}

\subsubsection{Food premises}

Until November 2017, total of premises that still joining this project are 25. Table 1 has shown the list and location of the premises that take their part in this project. .

Table 1. List of food premises participated simplified by area in Perlis.

\begin{tabular}{|c|c|c|}
\hline No. & Premise Name & Area \\
\hline 1. & Ziezan Station & \multirow{10}{*}{ Kangar } \\
\hline 2. & Nasi Ayam Tip Top & \\
\hline 3. & Ummi Corner & \\
\hline 4. & Restoran Warisan Masyhur & \\
\hline 5. & Restoran D' Sinar & \\
\hline 6. & Iriss Café & \\
\hline 7. & Nasi Kerabu Abang Wan & \\
\hline 8. & $\begin{array}{l}\text { Nasi Arab Abou Arabic and } \\
\text { Western Cuisine }\end{array}$ & \\
\hline 9. & SK IPGM Perlis & \\
\hline 10. & SK Putra & \\
\hline 11 & SMK Sanglang & Sanglang \\
\hline 12. & Kedai Roti dan Kek & \multirow{8}{*}{$\begin{array}{l}\text { UNIMAP } \\
\text { Pauh }\end{array}$} \\
\hline 13. & TM Café & \\
\hline 14. & Aneka Nasi Berlauk & \\
\hline 15. & Kedai Minuman (Air Buah) & \\
\hline 16. & Nasi Campur (LOT 01) & \\
\hline 17. & Gerai Nasi Campur (Lot10) & \\
\hline 18. & $\begin{array}{l}\text { Masakan Panas/Ala Carte } \\
\text { (LOT 03) }\end{array}$ & \\
\hline 19. & Makanan Arab (Lot 06) & \\
\hline 20. & Kedai Makan Kak Yah Soto & \multirow{6}{*}{ Arau } \\
\hline 21 & Kedai Nasi Kandar Zakri & \\
\hline 22. & Gerai Wan Azmi & \\
\hline 23. & Gerai Zainon Fitri & \\
\hline 24. & Gerai Che Amah & \\
\hline 25. & SK Oran & \\
\hline
\end{tabular}

Based from the Fig. 2, it shows that the highest food waste generated were from schools canteen. It found out the low generation of food waste at the premises because of lack of interest to handle the compost and prefer the conventional way. Besides, the participants complaining about the smell occur during the compost process. The investigation has been done, and found out the bad smell occurred because of high moisture content. It was because the location of the compost bucket was exposed to the rain and some put under the leaking pipe. High moisture content tends to lower down the amount of oxygen access for the bacteria to grow and causes $\mathrm{H}^{2} \mathrm{~S}$ and $\mathrm{NH}_{3}$ gases to be released [11]. 


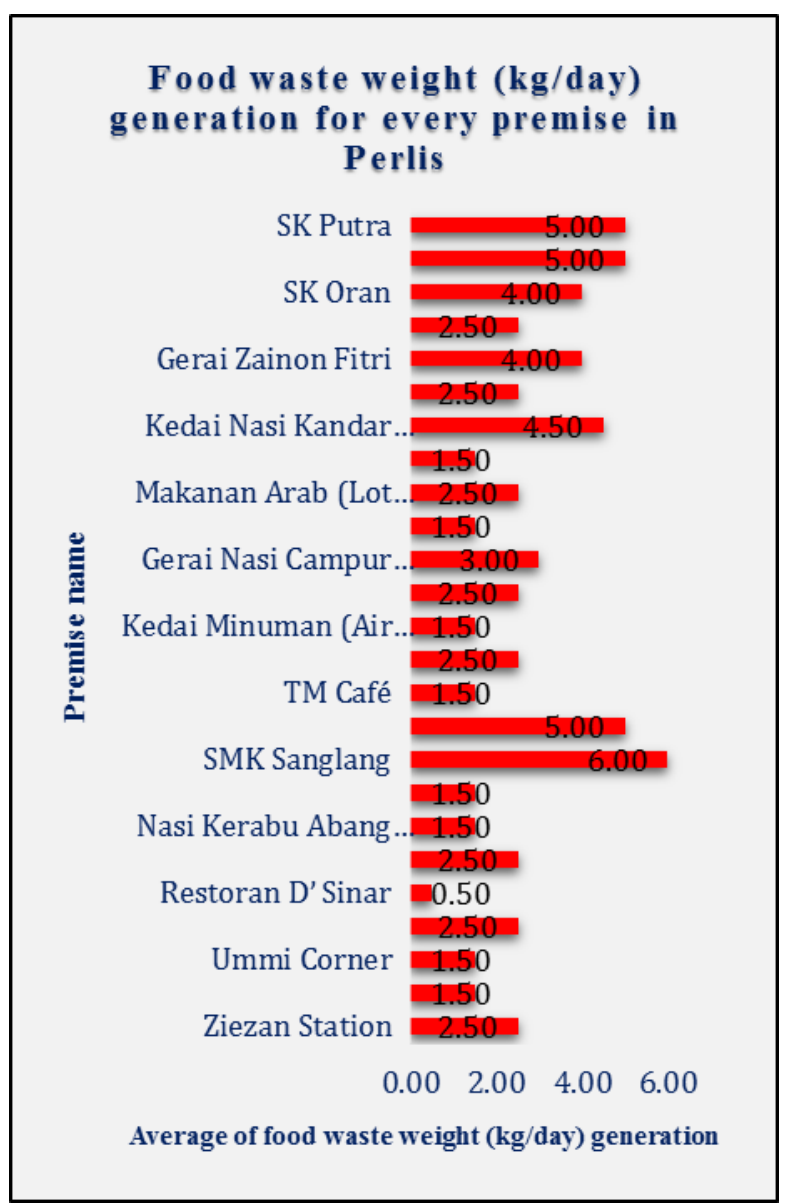

Fig .2. The average weight of food waste produce per day at every premise.

\subsubsection{Workshop on the Art of Composting}

The Art of Composting was successfully held on 18 April 2017. All participants enjoyed and gained knowledge regarding on food waste composting and it's beneficial to the environment. This program held in two-way communication when speaker and participants kept changing opinions and knowledge on managing the waste produced. The participants were from various levels of citizens, staffs, university students, primary schools students and Kolej Vokasional Kangar students. Fig. 3 and Fig. 4 show the picture of workshop held. 


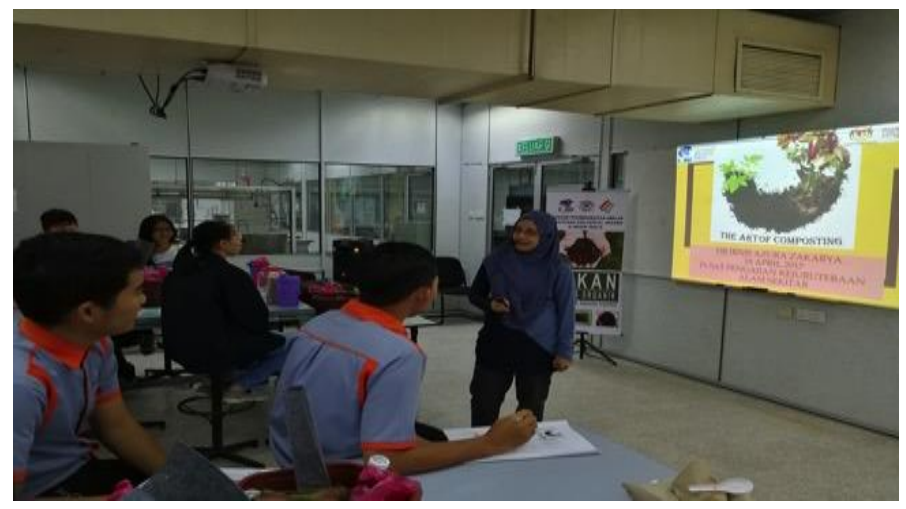

Fig. 3. Briefing session.

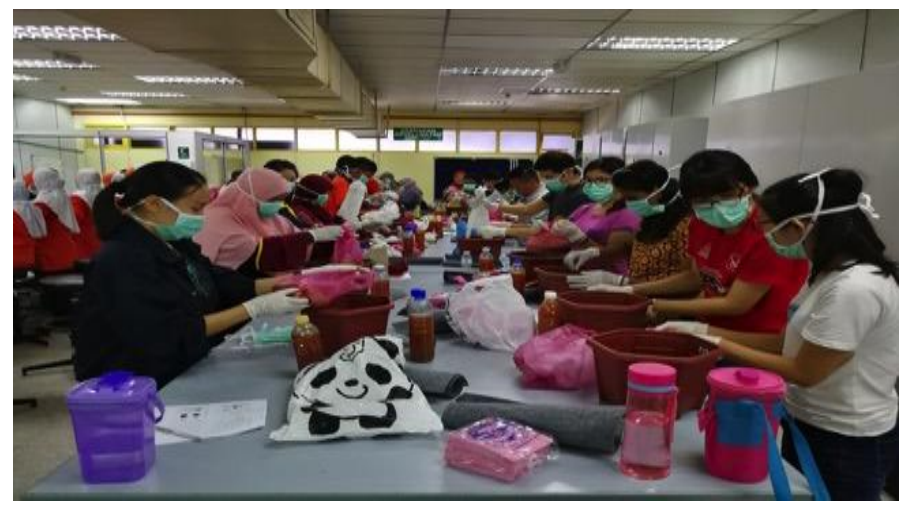

Fig. 4. Practical session.

At the end of the program, participants agreed that in order to keep our environment clean and to prolong our landfill lifespan, food waste composting is a good method and should be applied to all people in Malaysia. It looked difficult for the first time but once applied it, there should not be a problem anymore and no need to depend on chemical fertilizer anymore.

\subsection{Comparison of Nitrogen (N), Phosphorus (P) and Potassium (K)}

Table 2 shows the comparison of NPK value between the food waste compost, organic compost and chemical fertilizer. Food waste compost had low percentage on N, P and $\mathrm{K}$ compare to chemical fertilizer But NPK value of food waste compost is similar to cow dung. This happened because carbohydrate, protein and fat were assumed to be less and had gives the lowest value of NPK [13].

Table 2. NPK value between organic compost and chemical fertilizer. 


\begin{tabular}{|l|c|c|c|}
\hline \multicolumn{1}{|c|}{ Sample } & $\begin{array}{c}\mathbf{N} \\
\mathbf{( \% )}\end{array}$ & $\begin{array}{c}\mathbf{P} \\
\mathbf{( \% )}\end{array}$ & $\begin{array}{c}\mathbf{K} \\
\mathbf{( \% )}\end{array}$ \\
\hline $\begin{array}{l}\text { Food waste } \\
\text { compost }\end{array}$ & 1.39 & 0.47 & 0.07 \\
\hline Cow dung & 1.3 & 0.58 & 2.15 \\
\hline $\begin{array}{l}\text { Chemical } \\
\text { fertilizer }\end{array}$ & 20 & 40 & 25 \\
\hline
\end{tabular}

\section{Conclusions}

In conclusion, as conjunction of Separation at Source Program initiated by the Government (conducted by SWCorp), food waste composting could be the best way in reducing waste to the landfill. It perhaps can help to reduce almost 20 to 30 percent of total organic waste that has been dump onto the landfill before. Unfortunately, in order to have this target to be achieved, more works to be done especially on educating people from youngsters till the elders. Government much looks more seriously on having specific regulations on composting at food premises because most of the premises were the most contributor of producing food waste and kitchen waste to the landfill.

This program was funded by Knowledge Transfer Program (KTP) Scheme under Ministry of Higher Education Malaysia and supported by the Centre of Excellence for Biomass Utilization. The authors also wish to thank to School of Environmental Engineering, Universiti Malaysia Perlis and Solid Waste Corporation (SWCorp) Malaysia in this project.

\section{References}

1. N. Mekjinda,R. J. Ritchie, Waste Manag. 35, 199-206 (2015)

2. S. Sarkar, S. Pal, S. Chanda, Procedia Environ. Sci. 35, 435-440 (2016)

3. X. Wang, S. Pan, Z. Zhang, X. Lin, Y. Zhang, S. Chen, Bioresour. Technol. 224, 397404 (2017)

4. X. Qian, G. Shen, Z. Wang, C. Guo, Y. Liu, Z. Lei, Z. Zhang, Waste Manag. 34, 530535 (2014)

5. M. K. Manu,R. Kumar,A. Garg, Technol. 234, 167-177 (2017)

6. L. Zhang, X. Sun, Bioresour. Technol. 218, 335-343 (2016)

7. B. Nakhshiniev, M. K. Biddinika, H. B. Gonzales, H. Sumida, K. Yoshikawa, Bioresour. Technol., 151, 306-313 (2014)

8. R. Guo, G. Li, T, Jiang, F. Schuchardt, T. Chen, Y. Zhao, Y. Shen, Technol., 112, 171-178 (2012)

9. J.I. Chang, T.E. Hsu, Bioresour. Technol. 99, 8068-8074 (2008)

10. J. I. Chang, J. J. Tsai, K. H. Wu, Technol. 97, 116-122 (2006)

11. F.N.,Saad, M. Nadrah, N. Zain, S. Ezlin, N. Basri, N. Sofia, Jurnal Teknologi 2, 8995 (2013)

12. America Public Health Association (APHA), Standard Methods for Examination of Water and Wastewater, 21st ed., Washington DC, USA. (2005)

13. I. Zakarya, S. Khalib, T. Tengku Izhar, S. Yusuf. Engineering Research and Technology 4, 181-184 (2015) 